( 2021 , The Authors. Published by Elsevier Inc. and Fass Inc. on behalf of the American Dairy Science Association ${ }^{\circledR}$. This is an open access article under the CC BY-NC-ND license (http://creativecommons.org/licenses/by-nc-nd/4.0/).

\title{
The effects of organic grass and grass-birdsfoot trefoil pastures on Jersey heifer development: Heifer growth, performance, and economic impact
}

\author{
Jacob A. Hadfield, ${ }^{1} \odot$ Blair L. Waldron, ${ }^{2} \odot$ S. Clay Isom, ${ }^{1} \odot$ Ryan Feuz, ${ }^{3} \odot$ Ryan Larsen, ${ }^{3}$ J. Earl Creech, ${ }^{4} \odot$ \\ Marcus F. Rose, ${ }^{4} \odot$ Jenny Long, ${ }^{5} \odot$ Michael D. Peel, ${ }^{2} \odot$ Rhonda L. Miller, ${ }^{5} \odot$ Kerry A. Rood, ${ }^{1} \odot$ Allen Young, ${ }^{1} \odot$ \\ Rusty Stott, ${ }^{1}$ Alexis Sweat, ${ }^{1}$ and Kara J. Thornton ${ }^{1 *}$ (i) \\ ${ }^{1}$ Animal, Dairy, and Veterinary Sciences Department, Utah State University, Logan 84322-4815 \\ ${ }^{2}$ Forage and Range Research Laboratory, USDA-Agricultural Research Service, Logan 84322-6300 \\ ${ }^{3}$ Agricultural Economics Department, Utah State University, Logan 84322-4820 \\ ${ }^{4}$ Plants, Soils, and Climate Department, Utah State University, Logan 84322-4820 \\ ${ }^{5}$ Applied Sciences, Technology, and Education Department, Utah State University, Logan 84322-2300
}

\section{ABSTRACT}

Dairy heifers developed in certified organic programs, especially those utilizing pasture-based management schemes, have lower rates of gain than heifers raised in nonorganic confinement production systems in temperate climates, such as in the Intermountain West region of the United States. This study investigates the effects that different forages in a rotational grazing system have on development of organically raised Jersey heifers. Over 3 years, 210 yearling Jersey heifers were randomly assigned to one of 9 treatments, including a conventional confinement control where animals were fed a total mixed ration or one of 8 pasture treatments: Cache Meadow bromegrass (Bromus riparius Rehmann), QuickDraw orchard grass (Dactylis glomerata L.), Amazon perennial ryegrass (Lolium perenne L.), or Fawn tall fescue (Schendonorus arundinaceus [Schreb.] Dumort) and each individual grass interseeded with birdsfoot trefoil (Lotus corniculatus L., BFT). Each treatment had 3 blocks/yr over the 3 -yr period, with each block having a 0.4 ha pasture of each treatment. Every 35 d, over a 105-d period, heifers were weighed and measured for hip height, and blood samples were collected to determine serum insulin-like growth factor-1 and blood urea nitrogen concentrations. Fecal egg counts were also assessed. Heifer body weight (BW), blood urea nitrogen, and insulin-like growth factor-1 concentrations were affected by treatment when analyzed over time. Heifers on grass-BFT pastures had increased BW compared with heifers on monoculture grass pastures. Heifers receiving a total mixed ration or perennial ryegrass+BFT had increased $\mathrm{BW}$ gain over the 105-d period compared with heifers grazing

Received August 25, 2020.

Accepted June 18, 2021.

*Corresponding author: kara.thornton@usu.edu tall fescue+BFT, orchard grass, perennial ryegrass, meadow bromegrass, or tall fescue. Individually for all grass species, heifers grazing +BFT pastures had greater ending BW and weight gain than heifers grazing the respective grass monocultures. Furthermore, weight gain for heifers on perennial ryegrass $+\mathrm{BFT}$, meadow bromegrass $+\mathrm{BFT}$, and orchard grass $+\mathrm{BFT}$ were not different from those on a total mixed ration. Heifers grazing grass-BFT pastures had increased blood urea nitrogen compared with heifers grazing monoculture grass pastures. Heifer hip height and fecal egg counts were not affected by treatment. These results show that the addition of BFT to organic pasture improves growth of grazing replacement heifers. Economic analyses also demonstrate that interseeding grass pastures with BFT results in an increased economic return compared with grazing monoculture grass pastures. Grass pastures interseeded with BFT may be a sustainable option to achieve adequate growth of Jersey heifers raised in an organic pasture scenario in a temperate climate.

Key words: Jersey heifer, organic, pasture, birdsfoot trefoil

\section{INTRODUCTION}

Replacement heifer management is critical to maintain profitability in dairy operations. However, the cost of raising replacement heifers is the second largest expense incurred by dairies, behind only feed costs (Tozer and Heinrichs, 2001; Boulton et al., 2017). It is important that dairy heifers achieve appropriate growth to ensure maximum profitability and productivity. Previous research has demonstrated that prepubertal growth rates greater that $0.80 \mathrm{~kg} / \mathrm{d}$ in Holsteins result in a reduction in first lactation milk production (Zanton and Heinrichs, 2005). In contrast, Holstein calves with lower growth rates, between 0.40 and $0.56 \mathrm{~kg} / \mathrm{d}$, are older at both puberty and calving (Raeth-Knight et al., 
2009; Davis Rincker et al., 2011). Many producers are able to grow their heifers at a rate within these margins by utilizing a conventional feed system that consists of delivering a TMR in a confined area allowing for control of nutrient intake (Hoffman et al., 1996; Tozer et al., 2003). While efficient, this method can be costly, and producers welcome new strategies and alternatives to confined feeding. Additionally, organic producers must follow strict regulations, including a pasture requirement. As such, modern research aimed at finding ways to diminish expenses that do not negatively affect production, while still following organic requirements, is desired by producers (McBride and Greene, 2009).

Requirements for organic dairying, as established by the USDA, state that organic producers must let cattle graze pasture for the entire grazing season in their geographical region with a minimum of $120 \mathrm{~d}$ (USDAAMS, 2019), during which time $30 \%$ of the ruminant's DMI must come from pasture. To accommodate this regulation, many organic dairy producers feed a primarily pasture-based diet, which also helps reduce high organic feed costs. However, producers who used the highest amount of pasture-based forage $(75-100 \%)$ had the lowest net returns due to a $32 \%$ decrease in milk yield (McBride and Greene, 2009). Additionally, there is little research analyzing the effects of developing Jersey heifers on an organic pasture-based system in a temperate climate with little rainfall, such as that found in areas of the Intermountain West region of the United States.

To develop replacement heifers, pastures must provide nutrition that allows for adequate weight gain and skeletal growth, maintain or enhance reproductive performance, and improve rumen utilization of nitrogen. Utilizing grass-legume mixtures in pasture could help achieve these nutritional goals by supplying adequate amounts of herbage, energy, and protein. The ability of legumes to fix atmospheric nitrogen, leads to increased protein content of the pasture helping to improve forage yield and quality without application of fertilizers. Tannin-containing legumes could also improve production of ruminants on pasture. Research has shown that legumes containing tannins can increase nitrogen utilization in the rumen, decrease the incidence of bloat, and act as a natural anthelmintic to decrease parasite load (Min et al., 2003; Patra and Saxena, 2011). The use of legumes in grass pasture, especially those that contain tannins, could positively influence performance of developing dairy heifers. Previous research from our group indicates that grass pastures interseeded with birdsfoot trefoil (BFT), a tannin-containing legume, result in increased growth of beef steers (Waldron et al., 2020). Several other studies have analyzed performance of dairy heifers on pasture in other regions (Macdonald et al., 2007; Roche et al., 2015; Hayes et al., 2019); however, no previous research has investigated the effects of different organic pasture forages on development of Jersey heifers in a climate similar to that of the Intermountain West region of the United States. As such, the objective of the present study was to compare growth, health, and economic viability of Jersey heifers developed on an organic grass monoculture pasture, an organic grass pasture interseeded with a tannin-containing legume (BFT), or a conventional confinement setting (nonorganic). Our hypothesis states that Jersey heifers developed on organic grass pasture interseeded with BFT will have improved growth and health and be more economically viable when compared with heifers developed on organic monoculture grass pastures.

\section{MATERIALS AND METHODS}

All animal experiments were conducted following procedures approved by the Institutional Animal Care and Use Committee (IACUC protocol \#2777 and \#10063) at Utah State University. This study used 8 different pasture treatments and a TMR, for a total of 9 treatments. Each treatment used 3 blocks (pastures) per year over a 3 -yr period $(2016,2017$, and 2018). A total of 210 yearling Jersey heifers were purchased from commercial dairies (48 in 2016 from a single source, 81 in 2017 from a single source, and 81 in 2018 from 2 different sources). All heifers in the study were registered Jersey and had similar initial weights and birthdates. The experimental unit in the present study is pasture block. In 2016, 2 heifers were randomly allocated to one of 3 blocks in each pasture treatment and in 2017 and 2018, 3 heifers were randomly allocated to one of 3 blocks in each pasture or TMR treatment $(\mathrm{n}=9)$. In 2016, there were no Jersey heifers receiving a TMR; as such, the TMR treatment has an $\mathrm{n}=6$ and includes data collected in 2017 and 2018. In May of each year, heifers were transported to the Intermountain Irrigated Pasture Project in Lewiston, Utah. Upon arrival, heifers began a 2-wk grazing acclimation period to ensure heifers could adequately consume forage from pastures. After the 2-wk transition period was completed, heifers were fasted for $12 \mathrm{~h}$ in preparation for initial sampling. As heifers were sampled at d 0, they were randomly assigned to one of 3 blocks within each pasture or TMR treatment.

\section{Treatments and Pasture Information}

Pasture Information. The pastures used in the present study have been described previously (Rose et 
al., 2021). In brief, this research was conducted at the Utah State University Intermountain Irrigated Pasture Research Farm $\left(41^{\circ} 57^{\prime} 01.85^{\prime \prime}\right.$ N, 111 $52^{\prime} 15.75^{\prime \prime}$ W, elevation $1,369 \mathrm{~m}, 46 \mathrm{~cm}$ annual precipitation, and 56.1 precipitation d/yr) located near Lewiston, Utah. The soils at the site are a Kidman fine sandy loam (coarseloamy, mixed, superactive, mesic Calcic Haploxerolls) and Lewiston fine sandy loam (coarse-loamy, mixed, superactive, mesic Calcic Haploxerolls). The site is within the semiarid Central Great Basin region of the western United States, characterized by hot, dry summers, and most of the annual precipitation as snowfall. In this particular area (Cache County, Utah), the precipitation from winter snowfall is stored in reservoirs and used in the summer for irrigated crop production (Utah Climate Center, 2018). Yearly precipitation and temperature data for 2016, 2017, and 2018 are presented in Rose et al. (2021).

Pasture Treatments. This study used 8 different pasture treatments and a confinement TMR control. The 8 pasture treatments consisted of 4 monoculture grass pastures and 4 mixed pastures. The 4 monoculture grasses used were cache meadow bromegrass (Bromus riparius Rehmann; MB), QuickDraw orchard grass (Dactylis glomerata L.; OG), Amazon perennial ryegrass (Lolium perenne L.; PR), or fawn tall fescue (Schendonorus arundinaceus [Schreb.] Dumort; TF). Mixed pastures consisted of one of the 4 monoculture grasses listed previously, mixed with BFT $(\mathrm{MB}+\mathrm{BFT}$, $\mathrm{OG}+\mathrm{BFT}, \mathrm{PR}+\mathrm{BFT}, \mathrm{TF}+\mathrm{BFT})$. All heifers on pasture had access to water and a trace mineral supplement. Pasture treatments were planted at the Intermountain Irrigated Pasture Project and were grazed for a 105-d period.

Three different blocks were used each year of the study, with each block consisting of a 0.4-ha pasture of each treatment that was divided evenly into five 0.08 ha paddocks. Paddocks were separated with a single strand of poly-wire charged by a battery-powered fence charger. Rotational stocking was used with a stocking period of $7 \mathrm{~d}$, followed by a rest period of $28 \mathrm{~d}$, such that the entire rotation cycle was $35 \mathrm{~d}$. Three full rotations occurred each year, giving heifers a total of 105 d on pasture (June 20 to October 13, 2016; May 17 to August 30, 2017; and May 16 to August 29, 2018). At the end of each 35-d rotation cycle, heifers were gathered and fasted for $12 \mathrm{~h}$ for sample collection before resuming the next 35 -d cycle.

This study was conducted using organic dairy grazing protocols, so no treatment received commercial fertilizer. However, as previously described by Rose et al. (2021), approved organic sources of nitrogen were applied to the treatments. Chilean nitrate (sodium ni- trate, $15-0-2$, N-P-K; SQM) was applied at $28 \mathrm{~kg}$ of N $\mathrm{ha}^{-1}$ in April to all treatments (both monoculture and mixtures) in both 2017 and 2018. In addition, grass monocultures also received a second application of 28 $\mathrm{kg}$ of $\mathrm{N} \mathrm{ha}^{-1}$ of Chilean nitrate in July, and further received $35 \mathrm{~kg}$ of $\mathrm{N} \mathrm{ha}^{-1}$ in the form of hydrolyzed poultry feathers in June 2017 and March 2018 (80\% CP/6.25 = $12.8 \% \mathrm{~N}$ ) as a slow-release source of N. Paddocks were irrigated one week before grazing and within a week after grazing, so that pastures received $8.89 \mathrm{~cm}$ of water every 14 to $20 \mathrm{~d}$. Precipitation data for the site pasture samples were taken pre- and postgrazing to determine yield, as well as nutritional quality of the individual pasture. An in-depth analysis of pasture samples and DMI has been previously reported (Rose et al., 2021). Table 1 shows the average nutritional quality for each of the 9 treatments found from the analyses of pasture samples, as well as the TMR.

\section{Confinement Control}

Heifers assigned to the confinement control were fed a TMR and had access to water and a trace mineral supplement for the 105-d period of the experiment. The confinement control was only used in the study during years 2017 and 2018. The TMR composition (DM basis) for 2017 was $45 \%$ alfalfa haylage, $19 \%$ corn silage, $18 \%$ flaked corn grain, $9 \%$ beet pulp shreds, and 9\% wheat straw. The composition for the TMR in 2018 (DM basis) was $46 \%$ corn silage, $27 \%$ flaked corn grain, $22 \%$ alfalfa hay, and 5\% wheat straw. Year differences between TMR compositions were due to feed resource availability. For ease of access to feeds and feed equipment, heifers receiving the TMR were moved from the Intermountain Irrigated Pasture Project to the Caine Dairy Teaching and Research Farm in Wellsville, Utah. Control heifers were separated by block into 3 different pens, with 3 heifers per pen. Control heifers were fed to achieve average daily BW gains similar to those desired by local producers that develop dairy heifers. The TMR was fed daily at $0700 \mathrm{~h}$, and refusals were weighed, recorded, and discarded daily before feeding to determine intakes by block.

Every $7 \mathrm{~d}$, TMR samples were collected and stored at $-20^{\circ} \mathrm{C}$. After collecting TMR samples over the $35-\mathrm{d}$ period, one full grazing rotation, TMR samples were mixed and a composite sample taken. The composite sample was then sent to Cumberland Valley Analytical Services (Waynesboro, PA) for analysis. The TMR nutrition analyses, with the pasture treatment analyses, are shown in Table 1. Every 35 d, control heifers were gathered and fasted for $12 \mathrm{~h}$ before sample collection similar to the heifers receiving pasture treatments. 


\section{Sample Collection}

Samples from heifers were collected at 4 different time points: d 0, d 35, d 70, and d 105. All heifers were fasted for $12 \mathrm{~h}$ before sample collection. Weight, hip height, blood, and fecal samples were taken from each heifer at each time point. Weights were taken via an electronic scale. A regular hip height measuring stick
(Sullivan Supply) was used to determine hip height. Blood samples were collected via jugular venipuncture, using red top tubes, and allowed to clot at room temperature for $30 \mathrm{~min}$ before being stored and transported in a portable cooler. Fecal samples were collected in 50-mL conical tubes, put on ice, and taken to the Utah Veterinary Diagnostic Laboratory for analysis of FEC. Fecal samples from 2017 were analyzed using the

Table 1. Nutrient analysis of individual pasture treatments and TMR, averaged over $3 \mathrm{yr}$ and separated by sampling period

\begin{tabular}{|c|c|c|c|c|c|c|c|}
\hline Day & Treatment $^{1}$ & $\mathrm{CP}(\%)$ & $\operatorname{ADF}(\%)$ & $\operatorname{aNDF}^{2}(\%)$ & Fat $(\%)$ & $\mathrm{ME}^{3}$ (Mcal/kg) & $\operatorname{Ash}(\%)$ \\
\hline \multirow{6}{*}{$0-35$} & $\mathrm{MB}+\mathrm{BFT}$ & 13.90 & 37.86 & 57.27 & 2.07 & 2.85 & 9.25 \\
\hline & OG & 8.43 & 37.11 & 60.55 & 2.71 & 2.68 & 11.08 \\
\hline & $\mathrm{PR}$ & 8.16 & 30.70 & 47.76 & 2.54 & 3.01 & 11.51 \\
\hline & $\mathrm{PR}+\mathrm{BFT}$ & 16.37 & 30.08 & 42.42 & 2.19 & 3.12 & 10.18 \\
\hline & $\mathrm{TF}$ & 8.54 & 36.74 & 57.11 & 2.09 & 2.63 & 13.39 \\
\hline & MX & 14.69 & 33.76 & 49.81 & 2.20 & 2.88 & 9.95 \\
\hline \multirow[t]{6}{*}{$35-70$} & MB & 9.48 & 43.25 & 63.05 & 2.56 & 2.46 & 11.43 \\
\hline & $\mathrm{MB}+\mathrm{BFT}$ & 16.33 & 36.70 & 53.66 & 2.17 & 2.63 & 11.76 \\
\hline & $\mathrm{OG}$ & 9.23 & 39.51 & 63.41 & 3.22 & 2.48 & 12.53 \\
\hline & $\mathrm{OG}+\mathrm{BFT}$ & 13.97 & 36.67 & 56.86 & 2.74 & 2.67 & 12.66 \\
\hline & $\mathrm{PR}$ & 8.79 & 35.45 & 55.26 & 2.89 & 2.64 & 13.30 \\
\hline & MX & 15.08 & 35.71 & 52.79 & 2.30 & 2.62 & 12.80 \\
\hline \multirow[t]{11}{*}{ 70-105 } & $\mathrm{MB}$ & 11.69 & 40.34 & 59.14 & 3.04 & 2.57 & 12.00 \\
\hline & $\mathrm{MB}+\mathrm{BFT}$ & 17.09 & 34.31 & 51.56 & 2.68 & 2.78 & 12.21 \\
\hline & $\mathrm{OG}$ & 11.54 & 35.98 & 59.42 & 3.75 & 2.58 & 13.19 \\
\hline & $\mathrm{OG}+\mathrm{BFT}$ & 14.53 & 34.46 & 54.74 & 3.27 & 2.76 & 13.34 \\
\hline & $\mathrm{PR}$ & 12.60 & 33.25 & 51.66 & 3.03 & 2.69 & 13.22 \\
\hline & $\mathrm{PR}+\mathrm{BFT}$ & 19.06 & 30.58 & 41.24 & 2.17 & 2.72 & 12.79 \\
\hline & $\mathrm{TF}$ & 9.51 & 37.97 & 58.38 & 2.68 & 2.43 & 15.83 \\
\hline & $\mathrm{TF}+\mathrm{BFT}$ & 14.15 & 34.41 & 52.46 & 2.56 & 2.56 & 15.81 \\
\hline & TMR & 13.40 & 32.45 & 43.36 & 2.42 & 2.28 & 8.11 \\
\hline & MONO & 11.34 & 36.88 & 57.15 & 3.13 & 2.57 & 13.56 \\
\hline & MX & 16.21 & 33.44 & 50.00 & 2.67 & 2.71 & 13.54 \\
\hline \multirow[t]{2}{*}{$0-105$} & MB & 10.06 & 41.09 & 61.1 & 2.63 & 2.59 & 11.26 \\
\hline & $\mathrm{MB}+\mathrm{BFT}$ & 15.77 & 36.29 & 54.16 & 2.31 & 2.75 & 11.07 \\
\hline
\end{tabular}

${ }^{1}$ Treatments include meadow bromegrass (MB), meadow bromegrass + birdsfoot trefoil (BFT; MB+BFT), orchard grass (OG), orchard grass + BFT $(\mathrm{OG}+\mathrm{BFT})$, perennial ryegrass $(\mathrm{PR})$, perennial ryegrass + BFT (PR+BFT), TMR, average of all monoculture grass pastures $(\mathrm{MONO})$, and average of all grass + BFT mixed pastures (MX). The TMR confinement control was only used in the study during years 2017 and 2018 . The TMR composition (DM basis) for 2017 was $45 \%$ alfalfa haylage, $19 \%$ corn silage, $18 \%$ flaked corn grain, $9 \%$ beet pulp shreds, and $9 \%$ wheat straw. The composition for the TMR in 2018 (DM basis) was $46 \%$ corn silage, $27 \%$ flaked corn grain, $22 \%$ alfalfa hay, and $5 \%$ wheat straw. All treatments have $\mathrm{n}=9$, except TMR, which has $\mathrm{n}=6$.

${ }^{2} \mathrm{NDF}$ determined by amylase.

${ }^{3} \mathrm{ME}$ calculated as total digestible nutrient $\times 0.04409 \times 0.82(\mathrm{NRC}, 2001)$. 
Wisconsin Sugar Flotation Test (David and Lindquist, 1982), and the 2018 samples were analyzed using the McMaster Egg Counting Technique (Mines, 1977).

\section{Serum Metabolite Profiling}

After blood collection, tubes were stored at $4^{\circ} \mathrm{C}$ for $24 \mathrm{~h}$. Blood samples were then centrifuged at 1,000 $\times$ $g$ for $15 \mathrm{~min}$ at $4^{\circ} \mathrm{C}$. Serum was removed from blood samples and stored at $-20^{\circ} \mathrm{C}$ for subsequent analysis of BUN and IGF-1. A commercially available colorimetric assay was used to detect BUN in duplicate (Invitrogen, Urea Nitrogen Colorimetric Detection Kit; ThermoFisher Scientific). Serum samples were analyzed for IGF-1 in duplicate using the Human IGF-1 Quantikine ELISA Kit (SG100; R\&D Systems). This kit has been shown to have $100 \%$ cross-reactivity with bovine IGF-1 (Moriel et al., 2012).

\section{Economic Analysis}

For economic comparisons, the total establishment costs, net annual financial impact, payback period, and break-even organic premium of each treatment were calculated. The results were benchmarked against a conventional replacement dairy heifer operation feeding a TMR in confinement. The economic comparisons were made assuming the heifers were raised to a weight of $250 \mathrm{~kg}$, bred, fed or grazed an additional $30 \mathrm{~d}$ to allow for pregnancy checks, and then subsequently sold as either open or bred conventional or organic heifers. All results were calculated assuming 100 animal units (AU), with an AU defined as a single Jersey heifer.

The total establishment costs for each pasture treatment were considered the initial investment into the treatment. As the pasture treatments consist of perennial forage species, only establishment costs of the first year were included. Establishment costs consisted of planting costs and seed cost. The planting costs were based on a 150-horsepower tractor and 15 -foot $(4.57 \mathrm{~m})$ drill. Planting costs consisted of repairs $(\$ 8.33 / \mathrm{h})$, fuel $(\$ 13.20 / \mathrm{h})$, lubrication $(\$ 1.98 / \mathrm{h})$, labor $(\$ 16.50 / \mathrm{h})$, and planter costs $(\$ 15.50 / \mathrm{h})$. With 2.94 ha planted per hour, total planting costs were $\$ 23.62 /$ ha for the monoculture treatments. Because the BFT mixed treatments were seeded twice to ensure proper seed depth of each species in the mix, costs associated with planting BFT mixed treatments were assumed twice $(\$ 47.24 / \mathrm{ha})$ those of the monocultures. The seed costs $(\$ /$ ha) ranged from $\$ 66.68 /$ ha $(\mathrm{TF})$ to $\$ 160.52 / \mathrm{ha}(\mathrm{OG}+\mathrm{BFT})$, based on previously described seeding rates (Rose et al., 2021). Planting and seed costs were combined to estimate the establishment costs $(\$ /$ ha $)$ for each of the treatments. Total establishment costs were calculated as the product of the establishment costs per hectare and the estimated required hectares for each pasture treatment. Mean herbage mass values from Rose et al. (2021) were used together with predicted DMI using previously described equations to calculate the required number of hectares for each treatment to produce the necessary feed assuming an 85\% harvest efficiency (Saha et al., 2010). The required number of hectares ranged on average from 6.5 ha $(\mathrm{MB}+\mathrm{BFT})$ to 16.6 ha $(\mathrm{PR})$.

The net annual financial impact was estimated using a partial budget. The partial budget included decreases expenses from TMR feed savings, as well as increased expenses from fertilization, irrigation, and the opportunity cost of the pasture treatment (land rent). The partial budget did not include labor to move the heifers to new plots, set up the electric fence, irrigate, mix and deliver the TMR daily, or clean the pens for the animals in confinement. For this analysis, the labor increases and cost savings were assumed equal between the pasture and confined fed animals. The decreased expense from reduced feeding of a TMR was estimated as the cost per kilogram DM of TMR (Utah prices were used to value the mixed ration) multiplied by the kilogram saved through grazing the selected pasture treatment. The average cost per kilogram DM of TMR for 2017 and 2018 was $\$ 0.175$. Assuming $7.31 \mathrm{~kg} \mathrm{DM} / \mathrm{AU}$ per day (TMR predicted DMI using the equation as outlined by Saha et al., 2010), over $113 \mathrm{~d}$ on feed (DOF) across $100 \mathrm{AU}$, the total TMR feed savings would be $\$ 14,456$. This savings was assumed constant across all pasture treatments. The DOF for each treatment and TMR were estimated using the ADG values for each treatment with a target weight to begin breeding of $250 \mathrm{~kg}$ (Duplessis et al., 2015; Heinrichs and Jones, 2016). The DOF estimated for each treatment were then increased by 30 additional days in the partial budget analysis to allow adequate time for pregnancy checks and subsequent sale of each heifer as either a short-bred or open heifer. The DOF ranged from $82.5 \mathrm{~d}(\mathrm{PR}+\mathrm{BFT})$ to $130.6 \mathrm{~d}(\mathrm{TF})$. The increased forage expense for each treatment was calculated as the product of total $\mathrm{kg}$ of feed required $[\mathrm{DOF} \times$ predicted $\mathrm{DMI} \times 100(\mathrm{AU})]$ and the forage value $(\$ / \mathrm{kg})$ calculated as follows:

$$
F V_{i}=\frac{L R}{\left(H M_{i} \times H E_{i}\right)}
$$

where $F V_{i}$ is the calculated forage value $(\$ / \mathrm{kg})$ for the $i$ th pasture treatment, $L R$ is the assumed irrigated land rental rate $\left(\$ /\right.$ hectare), $H M_{\mathrm{i}}$ is the pregraze herbage mass $\left(\mathrm{kg} / \mathrm{ha}\right.$ for the $i$ th pasture treatment, and $H E_{i}$ is the assumed harvest efficiency percentage (i.e., 85\%) for the ith pasture treatment. Forage value ranged on 
average from $\$ 0.07 / \mathrm{kg}(\mathrm{PR}+\mathrm{BFT})$ to $\$ 0.14 / \mathrm{kg}(\mathrm{PR})$. Additional increases to expenses arose from irrigation and the application of organic fertilizer. Irrigation expenses were included at $\$ 60.54 /$ ha (Pace et al., 2019). The annual fertilizer expenses for the selected pasture treatment were also included in the partial budget at a cost of $\$ 9.26 / \mathrm{kg}$ of $\mathrm{N}$ for the sodium nitrate and $\$ 9.19 /$ $\mathrm{kg}$ of $\mathrm{N}$ for the hydrolyzed poultry feathers. The final element of the partial budget was increased or decreased income from sale of replacement heifers. Whether the sale of replacement heifers represents an increase or decrease in income, as compared with a confined feeding system, depends on the assumed difference in heifer conception rate as well as the price premium placed on organic heifers. The equation used to calculate the net change in income between grazing on selected pasture treatments as compared with feeding TMR in confinement was

$$
\Delta I_{i}=\left(N_{i} \times O P\right)+\left[N_{i} \times \Delta C_{i} \times(P b-P o)\right],
$$

where $\Delta I_{i}$ is the net change in income for pasture treatment $i, N_{i}$ is the total number of replacement heifers grazing the $i$ th pasture treatment, $\Delta C_{i}$ is the change in conception rate for heifers grazed on the $i$ th pasture treatment as compared with heifers fed in a dry lot, $P o$ and $P b$ are the prices (\$/head) for open and bred conventional replacement heifers, respectively, and $O P$ is the organic price premium $(\$ /$ head). For all pasture fed heifers, a $5 \%$ decrease in conception rate was added, as compared with dry lot fed heifers, based on previous research demonstrating that AI pregnancy rates tended to be lower for grazing heifers as compared with dry lot fed heifers (Funston and Larson, 2011). In addition to this $5 \%$ reduction, the conception rate of monoculture grazed heifers was further reduced an additional 5\% for a total $10 \%$ reduction as compared with TMR fed heifers based on previous findings that decreased BW gain before breeding results in lower conception rates at first service (Hayes et al., 2019). Values of $\$ 800$ and $\$ 400 /$ head for conventional replacement bred and open Jersey heifers, respectively, were used with an organic premium added of $\$ 225 /$ head (average premium determined through discussion with local organic producers).

The payback period for each pasture treatment was calculated by dividing the total establishment costs of each treatment by the annual net financial impact estimated using the partial budget.

The break-even organic premium was estimated as the premium required on the sale of organic replacement dairy heifers necessary for the net financial impact of grazing a selected pasture treatment (as compared with feeding TMR) to equal $\$ 0$.

\section{Statistical Analysis}

Data were analyzed by use of a randomized complete block design with 9 different treatments arranged into 3 blocks. Each block served as the experimental unit, where each block is defined as the mean of the data collected from the individual heifers on that block; there were 2 heifers on each of 3 pasture blocks in 2016 and 3 heifers on each of 3 pasture blocks in both 2017 and 2018. In 2016, there were no heifers being fed a TMR in confinement. All statistical analyses were done using the Proc Mixed statement of SAS version 9.4 (SAS Institute). Two analyses were carried out in the data set. Treatment was analyzed as a fixed effect, comparing all 9 treatments and the average values from heifers on each block across the study. Pasture type, mixed with BFT (MX) or without (MONO), was also analyzed $(\mathrm{n}=36)$ as a fixed effect, to determine if the presence of BFT in pasture influenced heifer growth and development. Heifers receiving TMR were eliminated from the pasture type analysis. Measures of heifer performance were analyzed within and across sampling days with block and year included as random variables. For the across sampling days (e.g., grazing rotation cycles) analyses, day was considered a repeated measure and the best covariance model was used for each trait (mostly compound symmetry). Post hoc mean comparisons with LSD adjustments were completed to determine differences between individual treatments. Significance was determined at $P \leq 0.05$ for all comparisons. All values used for tables and figures are LSM.

\section{RESULTS}

\section{Body Weight}

Pasture Type. Heifer BW was affected by both pasture type $\times$ day $(P<0.01)$ and day $(P<0.01$; Figure 1). Additionally, heifers who grazed MX pastures tended $(P=0.06)$ to have greater $\mathrm{BW}$ when compared with heifers that grazed MONO pastures (Figure 1). Pasture type had no effect on heifer BW at d 0 or d $35(P=0.99, P=0.17$, respectively, Figure 1$)$, but at d 70 and d 105, the heifers grazing MX pastures had greater $(P<0.01)$ BW compared with heifers receiving MONO pasture (Figure 1). Over the 105-d period, heifer weight gain also differed $(P<0.01)$ between MONO and MX treatments, with heifers grazing MX pastures having greater weight gain compared with heifers grazing MONO pastures $(0.60 \mathrm{~kg} / \mathrm{d}$ and 0.49 $\mathrm{kg} / \mathrm{d}$, respectively; data not shown). Taken together, these data indicate that heifers grazing MX pastures had greater BW and weight gain when compared with heifers grazing MONO pastures. 


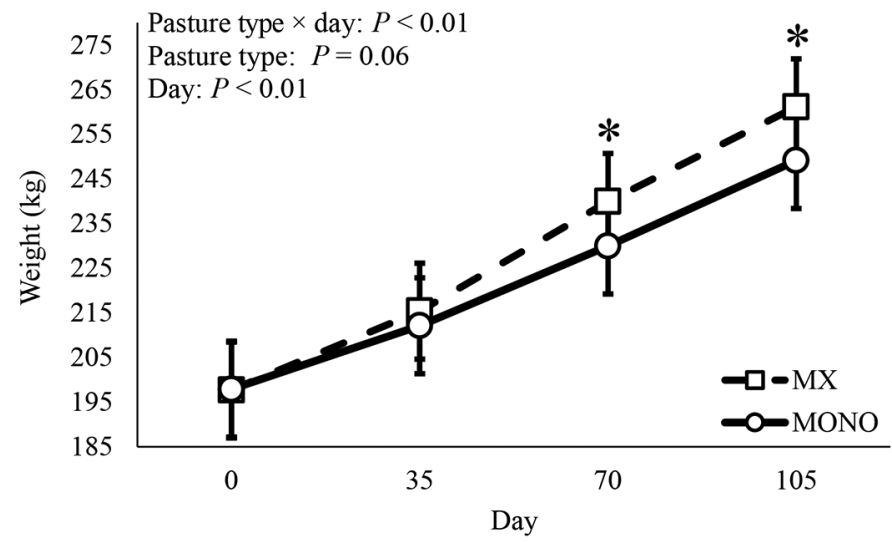

Figure 1. These data represent growth of Jersey heifers grazed in 2016, 2017, or 2018. A total of 192 heifers were used over the 3-yr period with 2 heifers per pasture in year 2016 and 3 heifers per pasture in 2017 and 2018. Each block of heifers serves as the experimental unit with treatments being either grass-only pastures (MONO, $\mathrm{n}=36$ ) or grass interseeded with birdsfoot trefoil (MX, $\mathrm{n}=36$ ). Weights were collected every $35 \mathrm{~d}$ over a 105-d period and analyzed to show the effects of pasture type $\times$ day, pasture type, and day. Differences $(P<$ $0.05)$ between pasture types within each time point are indicated with $a^{*}$. Error bars represent the SEM.

Treatment. Heifer BW was affected by treatment $\times$ day $(P<0.01)$, treatment $(P=0.01)$, and day $(P<$ $0.01)$. Treatment had no effect on heifer BW on d $0(P$ $=0.91)$ or $\mathrm{d} 35(P=0.14)$; however, BW was affected at d $70(P<0.01)$, and $\mathrm{d} 105(P<0.01)$. Additionally, over the 105 -d period, there was a change $(P<0.01)$ in gain (Table 2). At d 70 and d 105, heifers receiving TMR had greater $(P<0.05)$ BW compared with heifers grazing monoculture pastures $(\mathrm{PR}, \mathrm{OG}, \mathrm{MB}$, $\mathrm{TF}$ ) and $\mathrm{TF}+\mathrm{BFT}$ (Table 2). Similarly, heifers grazing $\mathrm{PR}+\mathrm{BFT}$ had greater $(P<0.05) \mathrm{BW}$ at $\mathrm{d} 70$ and 105 when compared with all monoculture pastures, with the exception of PR at d 70 (Table 2). Heifer weight gain over the 105 -d period was greater $(P<0.05)$ for $\mathrm{PR}+\mathrm{BFT}$ than all other treatments except heifers receiving TMR (Table 2). Heifers grazing TF had the lowest $(P<0.05)$ weight gains of all treatments (Table 2 ). Greater weight gains were observed for all + BFT treatments, including $\mathrm{TF}+\mathrm{BFT}$, compared with their individual respective grass monocultures (Table 2). Overall, these data demonstrate that heifers receiving TMR or mixed pastures had greater BW and weight gains when compared with heifers grazing monoculture pasture grasses.

Hip Height. There were no pasture type $\times$ day $(P$ $=0.61)$ or treatment $\times$ day $(P=0.65)$ interactions, nor was there an effect of pasture type $(P=0.16)$ or treatment $(P=0.42)$ on heifer hip height (Table 3). Date of measurement was significant $(P<0.01)$ with hip height increasing over the course of the grazing season (Table 3). Total hip height gain over the 105-d grazing

Table 2. Effect of different treatments on heifer BW over the 105-d grazing period

\begin{tabular}{|c|c|c|c|c|c|c|}
\hline \multirow[b]{2}{*}{ Treatment $^{1}$} & \multicolumn{6}{|c|}{ Weight $^{2}(\mathrm{~kg})$} \\
\hline & d 0 & d 35 & d 70 & d 105 & Gain & $\mathrm{ADG}$ \\
\hline $\mathrm{MB}$ & 199 & 208 & $229^{\mathrm{de}}$ & $251^{\text {de }}$ & $52^{\mathrm{c}}$ & $0.50^{\mathrm{d}}$ \\
\hline $\mathrm{MB}+\mathrm{BFT}$ & 199 & 213 & $241^{\mathrm{abc}}$ & $262^{\mathrm{abc}}$ & $63^{\mathrm{b}}$ & $0.60^{\mathrm{c}}$ \\
\hline OG & 194 & 212 & $231^{\text {cde }}$ & $251^{\text {de }}$ & $56^{\mathrm{c}}$ & $0.53^{\mathrm{d}}$ \\
\hline $\mathrm{OG}+\mathrm{BFT}$ & 198 & 215 & $238^{\text {abcd }}$ & $262^{\mathrm{abc}}$ & $64^{\mathrm{b}}$ & $0.61^{\mathrm{bc}}$ \\
\hline $\mathrm{PR}$ & 198 & 215 & $236^{\mathrm{bcd}}$ & $251^{\mathrm{cd}}$ & $53^{\mathrm{c}}$ & $0.51^{\mathrm{d}}$ \\
\hline $\mathrm{PR}+\mathrm{BFT}$ & 195 & 217 & $243^{\mathrm{ab}}$ & $265^{\mathrm{ab}}$ & $71^{\mathrm{a}}$ & $0.67^{\mathrm{a}}$ \\
\hline $\mathrm{TF}$ & 199 & 210 & $223^{\mathrm{e}}$ & $240^{\mathrm{e}}$ & $41^{\mathrm{d}}$ & $0.39^{\mathrm{e}}$ \\
\hline $\mathrm{TF}+\mathrm{BFT}$ & 198 & 217 & $238^{\text {bcd }}$ & $255^{\mathrm{bcd}}$ & $57^{\mathrm{c}}$ & $0.54^{\mathrm{d}}$ \\
\hline TMR & 202 & 225 & $250^{\mathrm{a}}$ & $271^{\mathrm{a}}$ & $70^{\mathrm{ab}}$ & $0.67^{\mathrm{ab}}$ \\
\hline SEM & 9.4 & 9.5 & 12.1 & 10.9 & 0.1 & 0.03 \\
\hline Treatment $\times$ day $^{3}$ & & & & $P<0.01$ & - & - \\
\hline Treatment $^{3}$ & & & & $P=0.01$ & $P<0.01$ & $P<0.01$ \\
\hline $\mathrm{Day}^{3}$ & & & & $P<0.01$ & - & - \\
\hline
\end{tabular}

${ }^{\mathrm{a} e}$ Means within each column that have a different superscript represent differences $(P<0.05)$ between treatments within each time point. Those with treatment differences indicated by superscripts had an overall treatment effect of $P<0.05$.

${ }^{1}$ Treatments include meadow bromegrass $(\mathrm{MB})$, meadow bromegrass + birdsfoot trefoil $(\mathrm{BFT}$; $\mathrm{MB}+\mathrm{BFT})$, orchard grass $(\mathrm{OG})$, orchard grass $+\mathrm{BFT}(\mathrm{OG}+\mathrm{BFT})$, perennial ryegrass $(\mathrm{PR})$, perennial ryegrass $+\mathrm{BFT}$ $(\mathrm{PR}+\mathrm{BFT})$, and TMR. The confinement control was only used in the study during years 2017 and 2018. The TMR composition (DM basis) for 2017 was $45 \%$ alfalfa haylage, 19\% corn silage, $18 \%$ flaked corn grain, $9 \%$ beet pulp shreds, and 9\% wheat straw. The composition for the TMR in 2018 (DM basis) was $46 \%$ corn silage, $27 \%$ flaked corn grain, $22 \%$ alfalfa hay, and $5 \%$ wheat straw. All treatments have $\mathrm{n}=9$, except TMR, which has $\mathrm{n}=6$.

${ }^{2}$ Values within columns represent LSM.

${ }^{3} P$-values for treatment $\times$ day, treatment, and day when heifer BW were analyzed over time with repeated measures. 
Table 3. Effect of different pasture treatments and pasture types on heifer hip height over the 105-d grazing period

\begin{tabular}{|c|c|c|c|c|c|}
\hline \multirow[b]{2}{*}{ Treatment $^{1}$} & \multicolumn{5}{|c|}{ Hip height $^{2}(\mathrm{~cm})$} \\
\hline & d 0 & d 35 & d 70 & d 105 & Gain \\
\hline MB & 111.9 & 113.8 & 115.8 & 117.6 & 5.6 \\
\hline $\mathrm{MB}+\mathrm{BFT}$ & 111.5 & 114.3 & 115.9 & 118.4 & 7.0 \\
\hline OG & 111.8 & 113.2 & 115.6 & 117.8 & 6.0 \\
\hline $\mathrm{OG}+\mathrm{BFT}$ & 112.2 & 113.6 & 116.1 & 118.1 & 5.9 \\
\hline $\mathrm{PR}$ & 112.3 & 113.9 & 115.3 & 118.1 & 5.9 \\
\hline $\mathrm{PR}+\mathrm{BFT}$ & 111.9 & 114.1 & 116.3 & 118.2 & 6.3 \\
\hline $\mathrm{TF}$ & 111.8 & 113.6 & 115.1 & 116.2 & 4.4 \\
\hline $\mathrm{TF}+\mathrm{BFT}$ & 112.5 & 114.4 & 116.8 & 118.2 & 5.7 \\
\hline TMR & 112.7 & 114.9 & 117.7 & 119.0 & 6.2 \\
\hline SEM & 1.9 & 1.7 & 1.9 & 1.3 & 1.0 \\
\hline Treatment $\times$ day $^{3}$ & & & & $P=0.65$ & - \\
\hline Treatment $^{3}$ & & & & $P=0.42$ & $P=0.08$ \\
\hline Day $^{3}$ & & & & $P<0.01$ & - \\
\hline \multicolumn{6}{|l|}{ Pasture type ${ }^{4}$} \\
\hline MX & 112.0 & 114.1 & 116.3 & 118.2 & $6.2^{\mathrm{a}}$ \\
\hline MONO & 111.9 & 113.6 & 115.4 & 117.5 & $5.5^{\mathrm{b}}$ \\
\hline SEM & 1.8 & 1.7 & 1.9 & 1.3 & 0.9 \\
\hline Pasture type $\times$ day $^{5}$ & & & & $P=0.61$ & - \\
\hline Pasture type & & & & $P=0.16$ & $P=0.05$ \\
\hline Day $^{5}$ & & & & $P<0.01$ & - \\
\hline
\end{tabular}

$\overline{\mathrm{a}, \mathrm{b}}$ Means within each column that have a different superscript represent differences $(P<0.05)$ between treatments within each time point. Those with treatment differences indicated by superscripts had an overall treatment effect of $P<0.05$.

${ }^{1}$ Treatments include meadow bromegrass $(\mathrm{MB})$, meadow bromegrass + birdsfoot trefoil $(\mathrm{BFT}$; MB+BFT), orchard grass $(\mathrm{OG})$, orchard grass $+\mathrm{BFT}(\mathrm{OG}+\mathrm{BFT})$, perennial ryegrass $(\mathrm{PR})$, perennial ryegrass $+\mathrm{BFT}$ $(\mathrm{PR}+\mathrm{BFT})$, TMR, average of all monoculture grass pastures, and average of all grass + BFT mixed pastures. The TMR confinement control was only used in the study during years 2017 and 2018. The TMR composition (DM basis) for 2017 was $45 \%$ alfalfa haylage, 19\% corn silage, $18 \%$ flaked corn grain, $9 \%$ beet pulp shreds, and $9 \%$ wheat straw. The composition for the TMR in 2018 (DM basis) was $46 \%$ corn silage, $27 \%$ flaked corn grain, $22 \%$ alfalfa hay, and $5 \%$ wheat straw. All treatments have $\mathrm{n}=9$, except TMR, which has $\mathrm{n}=6$.

${ }^{2}$ Values within columns represent LSM.

${ }^{3} P$-values for treatment $\times$ day, treatment, and day when heifer hip heights were analyzed over time with repeated measures.

${ }^{4}$ Pasture types include pastures with BFT (MX) and pastures without BFT (MONO). Both MX and MONO pastures have $\mathrm{n}=36$.

${ }^{5} P$-values for pasture type $\times$ day, pasture type, and day when heifer hip heights were analyzed over time with repeated measures.

period was greater $(P=0.05)$ in heifers grazing MX pasture (Table 3); whereas, 105-d change in hip height among the 9 treatments only approached significance $(P=0.08)$ (Table 3$)$. These data indicate that although pasture type did not alter hip height over time, the heifers were indeed growing as the trial progressed.

\section{Blood Urea Nitrogen}

Pasture Type. Heifer BUN concentrations were affected by pasture type $\times$ day $(P<0.01)$ and pasture type $(P<0.01)$ when analyzed over time (Figure 2$)$. At d 0 heifer BUN concentrations did not differ $(P=$ 0.20 ) between pasture types (Figure 2). However, heifers receiving MX pastures had greater $(P<0.01)$ BUN concentrations compared with heifers grazing MONO pastures at d 35, d70, and 105 (Figure 2). These data indicate heifers grazing MX pastures had greater BUN concentrations when compared with heifers grazing MONO pastures.

Treatment. Heifer BUN concentrations were not affected by a treatment $\times$ day $(P=0.12)$ interaction or day $(P=0.32)$, but treatment $(P<0.01)$ had an effect (Table 4). At d 0 heifer BUN did not differ $(P=0.79)$ between treatments (Table 4). However, at d 35, 70, and 105 heifer BUN concentrations differed $(P<0.01)$ between treatments (Table 4). At d 35, heifers receiving $\mathrm{PR}+\mathrm{BFT}, \mathrm{OG}+\mathrm{BFT}$ and TMR had greater $(P<0.05)$ BUN concentrations compared with heifers grazing all monoculture treatments (PR, OG, MB, TF, Table 4). At d 70, heifers grazing $\mathrm{PR}+\mathrm{BFT}$ and $\mathrm{OG}+\mathrm{BFT}$ had greater $(P<0.05)$ BUN levels compared with heifers grazing monoculture treatments $(\mathrm{OG}, \mathrm{PR}, \mathrm{MB}, \mathrm{TF})$ and TF+BFT (Table 4). At d 105, BUN levels were increased $(P<0.05)$ in heifers getting TMR, MB+BFT, $\mathrm{PR}+\mathrm{BFT}$, or $\mathrm{TF}+\mathrm{BFT}$ when compared with those 


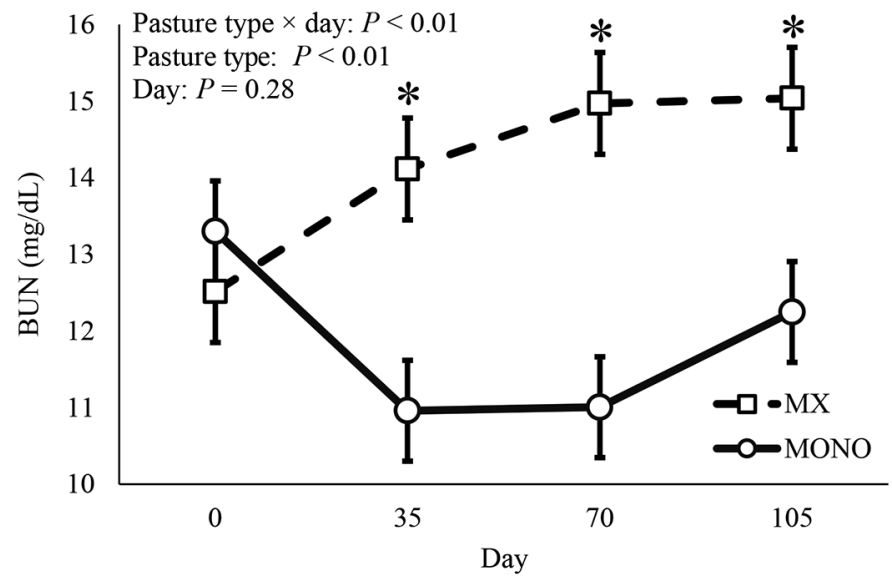

Figure 2. These data represent BUN concentrations of Jersey heifers grazed in 2016, 2017, or 2018. A total of 192 heifers were used over the 3 -yr period with 2 heifers per pasture in year 2016 and 3 heifers per pasture in 2017 and 2018. Each block of heifers serves as the experimental unit with treatments being either grass-only pastures (MONO, $\mathrm{n}=36$ ) or grass interseeded with birdsfoot trefoil (MX, $\mathrm{n}=36$ ). Blood samples were collected every $35 \mathrm{~d}$ over a 105 -d period and were quantified and analyzed to show the effects that pasture type $\times$ day, pasture type, and day can have on heifer BUN concentrations. Differences $(P$ $<0.05)$ between pasture types within each time point are indicated with a *. Error bars represent the SEM.

Table 4. Effect of different pasture treatments on heifer BUN concentrations over the 105-d grazing period

\begin{tabular}{lcccc}
\hline & \multicolumn{4}{c}{ BUN $^{2}(\mathrm{mg} / \mathrm{dL})$} \\
\cline { 2 - 5 } Treatment $^{1}$ & $\mathrm{~d} 0$ & $\mathrm{~d} 35$ & $\mathrm{~d} 70$ & $\mathrm{~d} 105$ \\
\hline MB & 12.3 & $9.9^{\mathrm{c}}$ & $10.3^{\mathrm{d}}$ & $11.6^{\mathrm{de}}$ \\
MB+BFT & 12.1 & $13.2^{\mathrm{ab}}$ & $14.7^{\mathrm{ab}}$ & $16.3^{\mathrm{a}}$ \\
OG & 13.6 & $11.5^{\mathrm{bc}}$ & $13.1^{\mathrm{bc}}$ & $14.7^{\mathrm{abc}}$ \\
OG+BFT & 12.3 & $14.4^{\mathrm{a}}$ & $16.0^{\mathrm{a}}$ & $14.9^{\mathrm{abc}}$ \\
PR & 13.2 & $11.3^{\mathrm{bc}}$ & $10.5^{\mathrm{cd}}$ & $13.1^{\mathrm{cd}}$ \\
PR+BFT & 12.7 & $15.4^{\mathrm{a}}$ & $16.1^{\mathrm{a}}$ & $15.8^{\mathrm{ab}}$ \\
TF & 13.7 & $10.1^{\mathrm{c}}$ & $9.7^{\mathrm{d}}$ & $10.2^{\mathrm{e}}$ \\
TF+BFT & 12.9 & $13.4^{\mathrm{ab}}$ & $13.1^{\mathrm{bc}}$ & $13.2^{\mathrm{cd}}$ \\
TMR & 12.6 & $15.4^{\mathrm{a}}$ & $14.9^{\mathrm{ab}}$ & $13.3^{\mathrm{bcd}}$ \\
SEM & 2.2 & 1.4 & 1.7 & 1.1 \\
Treatment $\times$ day $^{3}$ & & & & $P=0.12$ \\
Treatment & & & & $P<0.01$ \\
Day $^{3}$ & & & & $P=0.32$ \\
\hline
\end{tabular}

${ }^{\mathrm{a} e}$ Means within each column that have a different superscript represent differences $(P<0.05)$ between treatments within each time point. Those with treatment differences indicated by superscripts had an overall treatment effect of $P<0.05$.

${ }^{1}$ Treatments include meadow bromegrass $(\mathrm{MB})$, meadow bromegrass + birdsfoot trefoil (BFT; MB+BFT), orchard grass (OG), orchard grass $+\mathrm{BFT}(\mathrm{OG}+\mathrm{BFT})$, perennial ryegrass $(\mathrm{PR})$, perennial ryegrass + BFT $(\mathrm{PR}+\mathrm{BFT})$, and TMR. The confinement control was only used in the study during years 2017 and 2018. The TMR composition (DM basis) for 2017 was $45 \%$ alfalfa haylage, 19\% corn silage, $18 \%$ flaked corn grain, $9 \%$ beet pulp shreds, and $9 \%$ wheat straw. The composition for the TMR in 2018 (DM basis) was $46 \%$ corn silage, $27 \%$ flaked corn grain, $22 \%$ alfalfa hay, and $5 \%$ wheat straw. All treatments have $\mathrm{n}=$ 9, except TMR, which has $\mathrm{n}=6$.

${ }^{2}$ Values within columns represent LSM.

${ }^{3} P$-values for treatment $\times$ day, treatment, and day when heifer BUN concentrations were analyzed over time with repeated measures. grazing monoculture grasses. These data indicate that heifers receiving mixed pasture treatments or TMR had greater BUN concentrations than heifers who grazed monoculture pasture treatments.

\section{Insulin-Like Growth Factor-1}

Pasture Type. Heifer serum IGF-1 concentrations were not affected by a pasture type $\times$ day $(P=0.14)$ interaction, nor was a pasture type $(P=0.87)$ effect observed (Table 5). These data indicate that heifer IGF-1 concentrations vary by day, but do not appear to be affected by the pasture type consumed.

Treatment. Heifer IGF-1 concentrations were not affected by a treatment $\times$ day $(P=0.23)$ interaction but treatment $(P<0.01)$ and day $(P<0.01)$ were found to have an effect when analyzed over time (Table 5). Heifer IGF-1 concentrations at d 0 did not differ $(P=0.85)$ by treatment. However, at d 35,70 , and 105 heifer IGF-1 concentrations differed $(P<0.05)$ between treatments (Table 5). At d 35, heifers receiving TMR had greater $(P<0.05)$ IGF-1 concentrations compared with heifers who grazed monoculture pastures (PR, MB, OG, TF), MB+BFT, OG+BFT and $\mathrm{TF}+\mathrm{BFT}$ (Table 5). Similarly, heifers grazing $\mathrm{PR}+\mathrm{BFT}, \mathrm{MB}+\mathrm{BFT}$, and $\mathrm{OG}+\mathrm{BFT}$ had greater $(P$ $<0.05)$ IGF-1 concentrations compared with heifers grazing TF. At d 70, heifers receiving TMR had greater $(P<0.05)$ IGF-1 concentrations compared with heifers grazing all other treatments, except for OG (Table 5). At d 105, heifers receiving TMR, MB or MB+BFT had increased $(P<0.05)$ IGF-1 concentrations compared with heifers grazing $\mathrm{TF}$ or $\mathrm{TF}+\mathrm{BFT}$ (Table 5). Heifer IGF-1 concentrations were not significantly different $(P<0.05)$ between each individual grass monoculture and its respective mixture with BFT. Taken together, these data indicate heifers receiving TMR, OG, and $\mathrm{PR}+\mathrm{BFT}$ commonly had greater IGF-1 levels than heifers receiving other treatments.

\section{Parasite Load}

Fecal egg count data collected in the years 2017 and 2018 were analyzed separately as different methods to determine FEC were used each year. In both 2017 and 2018 , a pasture type $\times$ day interaction was not found $(P=0.88$ and $P=0.76$, respectively) nor was a pasture type effect ( $P=0.28$ and $P=0.30$, respectively) present when heifer FEC were analyzed over time (data not shown). However, heifer FEC was affected $(P<0.01)$ by day in 2017 and 2018 (data not shown) such that FEC increased over time. Additionally, heifer FEC was not affected ( $P=0.55$ and $P=0.93$, respectively) by a treatment $\times$ day interaction in 2017 or 2018 , nor was a 
Table 5. Effect of different pasture treatments on heifer IGF-1 concentrations over the 105-d grazing period

\begin{tabular}{lcccc}
\hline & \multicolumn{4}{c}{ IGF-1 $^{2}(\mathrm{ng} / \mathrm{mL})$} \\
\cline { 2 - 5 } Treatment $^{1}$ & $\mathrm{~d} 0$ & $\mathrm{~d} 35$ & $\mathrm{~d} 70$ & $\mathrm{~d} 105$ \\
\hline MB & 150.9 & $136.1^{\mathrm{bc}}$ & $149.3^{\mathrm{bc}}$ & $178.3^{\mathrm{ab}}$ \\
MB+BFT & 153.1 & $151.1^{\mathrm{b}}$ & $148.4^{\mathrm{bc}}$ & $172.3^{\mathrm{ab}}$ \\
OG & 157.4 & $138.2^{\mathrm{bc}}$ & $159.5^{\mathrm{ab}}$ & $184.8^{\mathrm{a}}$ \\
OG+BFT & 158.3 & $148.6^{\mathrm{b}}$ & $146.9^{\mathrm{bc}}$ & $159.3^{\mathrm{bc}}$ \\
PR & 146.3 & $137.2^{\mathrm{bc}}$ & $147.0^{\mathrm{bc}}$ & $163.2^{\mathrm{abc}}$ \\
PR+BFT & 149.7 & $153.3^{\mathrm{ab}}$ & $151.2^{\mathrm{b}}$ & $184.3^{\mathrm{a}}$ \\
TF & 164.4 & $121.9^{\mathrm{c}}$ & $139.5^{\mathrm{bc}}$ & $141.9^{\mathrm{c}}$ \\
TF+BFT & 147.0 & $141.6^{\mathrm{bc}}$ & $130.0^{\mathrm{c}}$ & $142.3^{\mathrm{c}}$ \\
TMR & 164.2 & $180.3^{\mathrm{a}}$ & $179.4^{\mathrm{a}}$ & $184.2^{\mathrm{ab}}$ \\
SEM & 15.3 & 24.7 & 33.6 & 25.5 \\
Treatment $\times$ day $^{3}$ & & & & $P=0.23$ \\
Treatment & & & & $P<0.01$ \\
Day $^{3}$ & & & & $P<0.01$ \\
Pasture type & & & & \\
MX & & & & 143.7 \\
MONO & 152.0 & 148.7 & 143.9 & 164.5 \\
SEM & 154.7 & 134.3 & 148.5 & 24.6 \\
Pasture type $\times$ day $^{5}$ & 22.9 & 22.9 & 31.7 & $P=0.14$ \\
Pasture type & & & & $P=0.87$ \\
Day $^{5}$ & & & & $P<0.01$ \\
\hline
\end{tabular}

${ }^{a-c}$ Means within each column that have a different superscript represent differences $(P<0.05)$ between treatments within each time point. Those with treatment differences indicated by superscripts had an overall treatment effect of $P<0.05$.

${ }^{1}$ Treatments include meadow bromegrass (MB), meadow bromegrass + birdsfoot trefoil (BFT; MB+BFT) orchard grass (OG), orchard grass + BFT $(\mathrm{OG}+\mathrm{BFT})$, perennial ryegrass $(\mathrm{PR})$, perennial ryegrass + BFT $(\mathrm{PR}+\mathrm{BFT})$, and TMR. The confinement control was only used in the study during years 2017 and 2018. The TMR composition (DM basis) for 2017 was $45 \%$ alfalfa haylage, $19 \%$ corn silage, $18 \%$ flaked corn grain, $9 \%$ beet pulp shreds, and $9 \%$ wheat straw. The composition for the TMR in 2018 (DM basis) was $46 \%$ corn silage, $27 \%$ flaked corn grain, $22 \%$ alfalfa hay, and $5 \%$ wheat straw. All treatments have $\mathrm{n}=$ 9 , except TMR, which has $\mathrm{n}=6$.

${ }^{2}$ Values within columns represent LSM.

${ }^{3} P$-values for treatment $\times$ day, treatment, and day when heifer hip heights were analyzed over time with repeated measures.

${ }^{4}$ Pasture types include pastures with BFT (MX) and pastures without BFT (MONO). Both MX and MONO pastures have $\mathrm{n}=36$.

${ }^{5} P$-values for pasture type $\times$ day, pasture type, and day when heifer hip heights were analyzed over time with repeated measures. treatment effect $(P=0.32$ and $P=0.61$, respectively $)$ observed for either year (data not shown). However, a day effect $(P<0.01)$ was observed for both years when analyzed over time such that FEC increased over time (data not shown). These data indicate that there were no differences between treatments on FEC of the heifers.

\section{Effect of Time}

Body weight, hip height, and IGF-1 each changed $(P<0.01)$ over the $105 \mathrm{~d}$ sampling period (Table 6$)$. As expected, both BW and hip height increased $(P<$ 0.01 ) over time (Table 6$)$. Day $(P<0.01)$ influenced heifer IGF-1 concentrations (Table 6). Heifers sampled at $\mathrm{d} 105$ had increased $(P<0.05)$ IGF-1 concentrations when compared with heifers sampled at all other time points (Table 6). Heifers sampled at d 0 had increased $(P<0.05)$ IGF-1 concentrations when compared with heifers sampled at d 35 (Table 6$)$. No effects $(P=0.32)$ of day were observed in BUN (Table 6).

\section{Economic Results}

Pasture Type. The MX pastures had an increased $(P<0.05)$ total establishment cost when compared with the MONO pastures (Table 7). Additionally, MX pastures had an increased $(P<0.05)$ annual net financial impact and a lower $(P<0.05)$ payback period when compared with the MONO pastures (Table 7). The break-even organic premium for MX pastures was also lower $(P<0.05)$ than that of MONO pastures (Table 7 ). These data indicate that although the establishment cost is higher for MX pastures, the economic return from developing dairy heifers on a MX pastures is much greater than utilizing a MONO pasture.

Treatment. When comparing the MONO grass pastures, the total establishment cost of TF was lower $(P<$ 0.05) than MB, OG, and PR, whereas the total establishment cost of $\mathrm{PR}$ was increased $(P<0.05)$ compared with TF, MB, and OG (Table 7). Comparison of total

Table 6. The effect of sampling day on heifer BW, hip height, BUN concentration, and IGF-1 concentration over the 105-d grazing period

\begin{tabular}{|c|c|c|c|c|c|c|}
\hline \multirow[b]{2}{*}{ Variable } & \multicolumn{4}{|c|}{ Sampling day ${ }^{1}$} & \multirow[b]{2}{*}{ SEM } & \multirow[b]{2}{*}{ Day effect ${ }^{2}$} \\
\hline & 0 & 35 & 70 & 105 & & \\
\hline BW (kg) & $198^{\mathrm{d}}$ & $215^{\mathrm{c}}$ & $236^{\mathrm{b}}$ & $257^{\mathrm{a}}$ & 10 & $P<0.01$ \\
\hline Hip height $(\mathrm{cm})$ & $112.0^{\mathrm{d}}$ & $114.0^{\mathrm{c}}$ & $116.0^{\mathrm{b}}$ & $118.0^{\mathrm{a}}$ & 1.6 & $P<0.01$ \\
\hline BUN (mg/dL) & 13.0 & 12.7 & 13.0 & 13.7 & 0.5 & $P=0.32$ \\
\hline IGF-1 (ng/mL) & $155.9^{\mathrm{b}}$ & $145.6^{\mathrm{b}}$ & $149.2^{\mathrm{bc}}$ & $168.1^{\mathrm{a}}$ & 22.5 & $P<0.01$ \\
\hline
\end{tabular}


establishment costs among the MX pastures showed that $\mathrm{OG}+\mathrm{BFT}$ was increased $(P<0.05)$ compared with all 3 of the other MX pastures (Table 7). PR was the only MONO pasture that had an increased $(P<$ 0.05 ) total establishment cost when compared with TF + BFT and $\mathrm{OG}+\mathrm{BFT}$, but was decreased $(P<0.05)$ compared with OG + BFT (Table 7). Comparison of the annual net financial impact among the MX pastures showed that PR was lower $(P<0.05)$ than TF, $\mathrm{MB}$, and $\mathrm{OG}$, whereas $\mathrm{MB}$ and $\mathrm{OG}$ were increased $(P$ $<0.05$ ) when compared with both TF and PR (Table 7). The annual net financial impact was not different $(P>0.05)$ among the MX pastures, but the annual net financial impact of each of the MX pastures was increased $(P<0.05)$ when compared with each of the MONO pastures (Table 7 ). The payback period was similar $(P>0.05)$ between all 8 of the different pasture treatments (Table 7 ). The break-even organic premium was increased $(P<0.05)$ in $\mathrm{PR}$ compared with all other pasture treatments, whereas $\mathrm{MB}, \mathrm{OG}$, and $\mathrm{TF}$ were increased compared with each of the MX pastures (Table 7$)$. There was no difference $(P>0.05)$ in the break-even organic premium when comparing each of the MX pastures (Table 7). Taken together, these data demonstrate that interseeding a grass pasture with BFT results in an overall increased economic return, however there are no real differences noted between the different grasses interseeded with BFT.

\section{DISCUSSION}

Monitoring growth of dairy heifers is important as heifers must reach approximately $55 \%$ of their mature BW at breeding by 13 to 15 mo of age, allowing for a target age of first calving at 22 to 24 mo to be reached (Akins, 2016; Hayes et al., 2019). An age of first calving beyond 24 mo results in increased rearing costs stemming from increased days on feed an ultimately decreased producer profitability (Pirlo et al., 2000). The present study found that on average, Jersey heifers

Table 7. Pasture treatment total establishment costs, annual net financial impact, payback period, and breakeven organic premium ${ }^{1}$

\begin{tabular}{|c|c|c|c|c|}
\hline Treatment $^{2}$ & $\begin{array}{c}\text { Total } \\
\text { establishment } \\
\operatorname{cost}^{3}(\$)\end{array}$ & $\begin{array}{l}\text { Annual net } \\
\text { financial } \\
\operatorname{impact}^{4}(\$)\end{array}$ & $\begin{array}{c}\text { Payback } \\
\text { period } \\
(\mathrm{yr})^{5}\end{array}$ & $\begin{array}{l}\text { Break-even } \\
\text { organic } \\
\text { premium }^{6}(\$)\end{array}$ \\
\hline $\mathrm{MB}+\mathrm{BFT}$ & $1,923^{\mathrm{c}}$ & $26,246^{\mathrm{a}}$ & $0.073^{\mathrm{a}}$ & $-37^{\mathrm{c}}$ \\
\hline $\mathrm{PR}+\mathrm{BFT}$ & $1,888^{\mathrm{c}}$ & $25,701^{\mathrm{a}}$ & $0.073^{\mathrm{a}}$ & $-32^{\mathrm{c}}$ \\
\hline $\mathrm{TF}+\mathrm{BFT}$ & $2,021^{\mathrm{bc}}$ & $24,754^{\mathrm{a}}$ & $0.082^{\mathrm{a}}$ & $-22^{\mathrm{c}}$ \\
\hline $\mathrm{OG}+\mathrm{BFT}$ & $2,325^{\mathrm{a}}$ & $24,583^{\mathrm{a}}$ & $0.095^{\mathrm{a}}$ & $-20^{\mathrm{c}}$ \\
\hline MB & $1,543^{\mathrm{d}}$ & $13,582^{\mathrm{b}}$ & $0.128^{\mathrm{a}}$ & $90^{\mathrm{b}}$ \\
\hline $\mathrm{OG}$ & $1.702^{\mathrm{d}}$ & $12,659^{\mathrm{b}}$ & $0.151^{\mathrm{a}}$ & $99^{\mathrm{b}}$ \\
\hline $\mathrm{TF}$ & $1,322^{\mathrm{e}}$ & $9,528^{\mathrm{c}}$ & $0.153^{\mathrm{a}}$ & $130^{\mathrm{b}}$ \\
\hline $\mathrm{PR}$ & $2.114^{\mathrm{b}}$ & $-843^{\mathrm{d}}$ & $\mathrm{N} / \mathrm{A}$ & $234^{\mathrm{a}}$ \\
\hline \multicolumn{5}{|l|}{ Pasture type ${ }^{7}$} \\
\hline MX & $2,039^{\mathrm{a}}$ & $25,321^{\mathrm{a}}$ & $0.081^{\mathrm{a}}$ & $-28^{\mathrm{b}}$ \\
\hline MONO & $1,670^{\mathrm{b}}$ & $8,731^{\mathrm{b}}$ & $0.171^{\mathrm{b}}$ & $137^{\mathrm{a}}$ \\
\hline
\end{tabular}

${ }^{\mathrm{a}-\mathrm{e}}$ Values within each column that have a different superscript are different $(P<0.05)$ from one another. Those with treatment differences indicated by superscripts had an overall treatment effect of $P<0.05$.

${ }^{1}$ Estimates are based on 100 animal units of replacement dairy heifers with days on feed for each treatment equal to the number of days estimated to reach the optimal breeding weight of $250 \mathrm{~kg}$ plus 30 additional days to allow for pregnancy testing and sale as either short-bred heifer or open heifer.

${ }^{2}$ Treatments include meadow bromegrass (MB), meadow bromegrass + BFT (MB+BFT) orchard grass $(\mathrm{OG})$, orchard grass + BFT $(\mathrm{OG}+\mathrm{BFT})$, perennial ryegrass $(\mathrm{PR})$, perennial ryegrass + BFT $(\mathrm{PR}+\mathrm{BFT})$, and TMR. All treatments have $\mathrm{n}=9$, except TMR, which has $\mathrm{n}=6$.

${ }^{3}$ The total establishment costs for each pasture treatment are considered the initial cost of investment into the pasture treatments and are equal to the combined planting and seed costs $(\$ /$ ha) for each treatment multiplied by the total amount of hectares needed to produce the required forage. The required forage is the amount necessary for the days on feed of each treatment to allow the 100 animal units to reach the target breeding weight of $250 \mathrm{~kg}$, have pregnancy tests administered, and be sold as short-bred or open heifers.

${ }^{4}$ The annual net financial impact is the sum of the positive and negative changes within the partial budget of each pasture treatment.

${ }^{5}$ The payback period is calculated as the pasture treatment total establishment cost divided by the annual net financial impact. N/A indicates that the investment is expected to have a negative payback period, indicating it would never be expected to pay off.

${ }^{6}$ Break-even organic premium is the premium (\$/head) required on organic dairy heifers for the annual net financial impact of a pasture treatment to be equal to $\$ 0$.

${ }^{7}$ Pasture types include pastures with BFT (MX) and pastures without BFT (MONO). Both MX and MONO pastures have $\mathrm{n}=36$. 
grazing MX pastures had greater BW gain than heifers on MONO pastures. All heifers were weighed after a $12 \mathrm{~h}$ fast demonstrating that differences in weight were not due to differences in gut fill. The increased BW gain of heifers grazing MX pastures could be due to the fact that grass $+\mathrm{BFT}$ pastures had increased ME or $\mathrm{CP}$ when compared with grass monoculture pastures (Rose et al., 2021). To the knowledge of the authors, no other grazing studies have been conducted using Jersey heifers in the Intermountain West region of the United States on organic pastures. However, in a study utilizing beef heifers, Waldron et al. (2020) reported that beef steers grazing $\mathrm{TF}+\mathrm{BFT}$ had greater $\mathrm{BW}$ gain than those grazing TF monocultures. In another study conducted in the southern region of the United States, it was found that bred Holstein heifers grazing native big bluestem and Indiangrass had increased ADG compared with heifers grazing switchgrass, but no effects on ADG were observed when these grasses were interseeded with the legume red clover (Lowe et al., 2016). In another similar grazing study looking at Holstein heifers, it was reported that heifers grazing legume mixed pastures (alfalfa or BFT) had greater ADG (12-17\% increase) compared with heifers grazing grass pastures (Barker et al., 1999). Taken together, the results of these studies demonstrate that there are conflicting results on whether inclusion of legumes in pastures affect growth of grazing heifers. However, the research presented by Waldron et al. (2020) and the present study were both performed in a similar region using nonorganic or organic practices, respectively, and found interseeding grass pastures with BFT resulted in increased weight gain when grazed by growing beef steers or Jersey heifers. The differences in results from some of the other previously reported studies could be due to differences in breed (Holstein vs. Jersey), the type of grass (warm season vs. cool season) used in the research, or that the pastures used in the present study were treated organically.

Additionally, the results of the present study demonstrate that Jersey heifers receiving TMR had greater weight gains than all grass MONO pastures (PR, OG, MB, TF), but had similar BW gains to heifers grazing MX pastures. These data indicate that animals grazing organic mixed pastures in the Intermountain West region of the United States are capable of gaining as well as those receiving a nonorganic TMR. Previous research has found that 7-mo-old beef heifers fed TMR diets reached puberty 29 d younger than heifers grazing on dormant native pastures with no supplement (Marston et al., 1995). However, heifers grazing on pasture that received a $20 \% \mathrm{CP}$ supplement had similar weights at breeding as heifers in a dry lot (Marston et al., 1995). Although Marston et al. (1995) did not look at the effects of including legumes, which have a higher $\mathrm{CP}$ than grasses, their data demonstrates that heifers consuming grass plus additional $\mathrm{CP}$ results in similar weight gain to those receiving a TMR. Taken together, the results of the present study, and those of others, demonstrate that high-quality grasses interseeded with $\mathrm{BFT}$, or another source of $\mathrm{CP}$, result in overall heifer BW gains similar to those fed a TMR. As such, organic grass-BFT mixed pastures are a sustainable alternative to feeding a TMR in a confined setting and should be considered a viable option for sustainable ruminant production on pasture in regions such as the Intermountain West.

However, in addition to BW gain, it is also important that producers analyze structural growth of their heifers to ensure that heifers are growing structurally and not just putting on fat. Hip height is often used as a measurement for producers to determine structural growth of heifers. In the present study, heifer hip height was only affected by d of measurement, with increasing hip height throughout the grazing season indicating that no treatments had nutrient deficiencies that severely restricted body growth. Previous research providing Holstein heifers with either high forage ( $75 \%$ DM) or high concentrate ( $75 \%$ DM) found no difference in structural growth, but also did not see a difference in ADG, likely because DMI was matched between the 2 different treatments (Zanton and Heinrichs, 2007). The study by Zanton and Heinrichs (2007) analyzed 2 different diets with much more variable nutrient composition than the diets used in the present study and also observed no difference in hip height, but DMI was matched between the 2 diets. Another study found that increasing CP:ME ratio in the diet of Holstein heifers resulted in increased hip height (Gabler and Heinrichs, 2003). The CP:ME ratio in the present study likely did not vary enough to result in alteration in hip height.

Legumes have an increased CP concentration when compared with grasses. One physiological measure of protein intake is concentration of BUN. Research has shown that concentrations of BUN above $20 \mathrm{mg} / \mathrm{dL}$ may be detrimental to reproductive performance (Ferguson et al., 1988, 1993; Rajala-Schultz et al., 2001). As such, in the present study we wanted to ensure that Jersey heifers grazing the pastures interseeded with BFT did not have a BUN exceeding this level. In the present study, concentrations of BUN were greater in heifers that grazed MX pastures or received a TMR compared with those consuming MONO pasture. However, it is important to note that none of the BUN values exceeded $20 \mathrm{mg} / \mathrm{dL}$ and the greatest BUN concentration reported in the present study was $16.3 \mathrm{mg} /$ 
dL. In another study analyzing the influence of green grass-based diets it was found that diet had no effect on BUN concentration of crossbred dairy heifers (Habib et al., 2018). It was also found that increasing dietary concentrates in growing Holstein heifers resulted in a linear increase in BUN concentration (Zhang et al., 2018). However, studies done in lactating Jersey and Holstein cows grazing grass pasture have found that BUN levels stayed between 16 and $19 \mathrm{mg} / \mathrm{dL}$, which is similar to our research findings (Kolver and Macmillan, 1994; Roche et al., 2005). Holstein cows put on grass pastures fertilized with 40 to $50 \mathrm{~kg}$ of $\mathrm{N} /$ ha reached BUN levels of over $60 \mathrm{mg} / \mathrm{dL}$ (Ordóñez et al., 2007). In the present study, less $\mathrm{N}$ fertilizer $(28-37 \mathrm{~kg}$ of $\mathrm{N} / \mathrm{ha}$ ) was applied to monoculture pastures, with $\mathrm{CP}$ contents across all treatments ranging from 8 to $19 \%$, which is much lower than the previously cited studies and could be a reason why much lower BUN levels were reported. Additionally, no previous research has analyzed BUN levels of Jersey heifers grazing organic pastures.

The differences between heifer BUN concentrations from our research compared with the previously mentioned studies may also be due to the effect of CT from BFT. Condensed tannins have the ability to bind protein in the rumen, thus decreasing the amount of circulating urea in the animal (Min et al., 2003; Patra and Saxena, 2011). However, Rose et al. (2021) reported that CT levels among our research pastures ranged from 0.5 to $7.5 \mathrm{~g}$ of $\mathrm{CT} / \mathrm{kg}$ of $\mathrm{DM}$, whereas Min et al. (2003) reported that CT concentrations of 20 to $45 \mathrm{~g}$ of $\mathrm{CT} / \mathrm{kg}$ of $\mathrm{DM}$ were ideal in reducing rumen forage protein degradation. Thus, CT from BFT may have had an effect on our heifer BUN concentrations, but probably didn't result in as great a reduction of BUN as we originally hypothesized due to the low levels of CT in our BFT. The lower concentration of BUN found in this study could have also been influenced by sampling after a $12 \mathrm{~h}$ fast, because BUN concentrations reach their peak 4 to $6 \mathrm{~h}$ postprandial (Butler, 1998). Other data suggest that the optimal time to measure BUN in lactating cows was between 3 to $8 \mathrm{~h}$ after feeding, with $4 \mathrm{~h}$ after feeding being the optimal time (Hwang et al., 2001). More research needs to be conducted in Jersey heifers grazing organic pastures to determine how different pasture forages may affect BUN levels.

Serum IGF-1 levels may be an indicator of energy balance, but are not necessarily an indicator of overall nutrient balance (Kolver and Macmillan, 1994). In the present study, Jersey heifer IGF-1 concentrations did not differ between animals grazing MX or MONO pastures. Although heifers grazing MX pastures had increased weight gain compared with those consuming MONO pastures, no difference in circulating IGF-1 concentration was observed. However, our results indicate that IGF-1 concentrations from heifers receiving a TMR (the numerically highest ADG observed) were higher than heifers who received TF (the numerically lowest ADG observed) throughout the study. Additionally, other research has found that polymorphisms in the IGF-1 gene are related to growth of HolsteinFriesian heifers (Siadkowska et al., 2006; Mullen et al., 2011). Previous research in beef steers has analyzed the effects that different levels of energy and protein (low protein, low energy: $1.96 \mathrm{ME} / \mathrm{kg}$ and $8 \% \mathrm{CP}$ vs. medium protein, high energy: $2.67 \mathrm{ME} / \mathrm{kg}$ and $11 \%$ $\mathrm{CP}$ ) have on plasma IGF-1 and found that diet composition and intake influence plasma IGF-1 levels such that steers receiving medium protein and high energy diets had increased IGF-1 levels compared with steers receiving low protein and low energy diets (Elsasser et al., 1989). These researchers suggested that although $\mathrm{CP}$ may be responsible for basal IGF-1 levels, the actual IGF-1 response to diet may be more affected by available metabolizable energy (Elsasser et al., 1989). Similarly, in a study focusing on the effects of negative energy balance on the GH axis in lactating HolsteinFriesian cows, it was found that severe negative energy balance affected hepatic synthesis of IGF-1 (Fenwick et al., 2008). Previous research findings demonstrate that IGF-1 can be an indicator of energy balance (Elsasser et al., 1989; Kolver and Macmillan, 1994; Fenwick et al., 2008). However, in the present study the TMR had a numerically lower energy value than the TF pasture, despite the fact that the heifers receiving TMR had increased ADG compared with those grazing TF. These data do not match previous findings that increased energy increases circulating IGF-1 (Elsasser et al., 1989; Fenwick et al., 2008). However, the CP in the TMR was increased compared with the TF pasture, which indicates that our results might more closely match dietary $\mathrm{CP}$ as opposed to energy. This data demonstrates that research on ruminant IGF-1 plasma concentrations on pasture is scarce; more research is needed to determine the relationship between ruminant serum IGF-1 concentrations and pasture type, specifically of Jersey heifers grazing organic pastures.

The addition of BFT to pastures did not have any effect on Jersey heifer FEC in the present study. Studies have found that $\mathrm{CT}$ from BFT can decrease FEC in ruminants (Min et al., 2003). It has also been found that lambs grazing forages that contained CT had a reduction in FEC (Niezen et al., 1998). Other research has suggested that BFT may reduce FEC in dairy heifers (Shepley et al., 2015). The results of the current study do not agree with the findings of these previous studies. The differences in results may be due to the 
low amount of CT (0.5-7.5 g of CT/kg of DM) reported in our pastures by Rose et al. (2021). In addition, it should be noted that the Jersey heifers used in this study had low numbers of parasites overall, making it difficult to detect any differences in FEC. Although other research suggests feeding ruminants BFT can reduce parasite load, our results indicate that BFT had no effect on parasite load. As such, additional research needs to be completed to determine how different varieties of BFT in an organic pasture may affect parasite load of developing dairy heifers of different breeds.

The findings of the economic analysis in the present study demonstrate that all treatments other than PR are estimated to have a positive annual net financial effect. This indicates that once the establishment costs have been paid, producers could expect a positive effect annually from producing organic replacement dairy heifers on these pasture treatments as compared with conventional heifers fed in confinement. When comparing the monocultures with the BFT mixed pasture treatments, it is important to consider how the differing fertilization rate influenced the results. The monoculture pasture treatments received twice the amount of sodium nitrate as compared with the BFT mixed pasture treatments as well as the application of the hydrolyzed poultry feathers. Additionally, the monocultures required more hectares on average as compared with the BFT mixed treatments to produce the required feed (resulting from less biomass per hectare on average). This increased number of hectares along with the increased fertilization rate resulted in an average increase in fertilization expenses of $\$ 10,755$ within the partial budget for MONO pastures as compared with MX pastures. Fertilization requirements may vary and further investigation of the individual needs of each of the pasture treatments is required to more precisely evaluate the expected increases to fertilization expenses. Previous research comparing growth of beef steers consuming $\mathrm{TF}+\mathrm{BFT}, \mathrm{TF}+$ alfalfa, and $\mathrm{TF}+$ nonorganic $\mathrm{N}$ fertilizer found that steers consuming $\mathrm{TF}+\mathrm{BFT}$ gained more than the other treatments and had an increased gross economic return (Waldron et al., 2020). The results of the present study and those from Waldron et al. (2020) demonstrate that interseeding grass pastures with BFT results increased weight gains and economic returns, despite different fertilization methods. Previous research in the mid-south United States comparing native warm season grasses with and without legumes found that feeding switchgrass alone resulted in the greatest economic return (Lowe et al., 2016). These data demonstrate that analyzing economic return of heifers grazing pasture is highly variable between different locations, fertilization type and rate, and pasture type.

\section{CONCLUSIONS}

Interseeding a legume, BFT, with grasses in an organic pasture increases Jersey heifer weight gain when compared with those grazing a monoculture grass, but results were not different from those fed a conventional TMR. Furthermore, Jersey heifers grazing BFT mixed pastures had higher BUN concentration than animals on grass pastures. Even with higher levels of BUN, animals grazing BFT mixed pastures never surpassed BUN concentrations that are known to be detrimental to reproduction. Serum IGF-1 levels were also commonly higher in heifers fed a TMR compared with heifers grazing TF. Heifer parasite load and hip height were not affected by the presence of BFT in pasture or any of the specific treatments. This research demonstrates that grazing Jersey heifers on organic grass-BFT mixed pastures may be a sustainable method to improve dairy heifer development in animals consuming pasture in a temperate climate similar to that found in the Intermountain West region of the United States, especially those using an organic system.

\section{ACKNOWLEDGMENTS}

This work was supported by the USDA National Institute of Food and Agriculture (NIFA) through (1) Western Sustainable Agriculture Research and Education program (WSARE) grant no. 2016-38640-25383, subaward SW17-046, and (2) Organic Agriculture Research and Extension Initiative (OREI) grant no. 2017-51300-26866, project accession no UTA01375. The USDA is an equal opportunity employer and service provider. Mention of a trademark, proprietary product, or vendor does not constitute a guarantee or warranty of the product by the USDA or Utah State University. The authors have not stated any conflicts of interest.

\section{REFERENCES}

Akins, M. S. 2016. Dairy heifer development and nutrition management. Vet. Clin. North Am. Food Anim. Pract. 32:303-317.

Barker, J. M., D. D. Buskirk, H. D. Ritchie, S. R. Rust, R. H. Leep, D. J. Barclay, R. Adams, and G. Hartnell. 1999. Intensive grazing management of smooth bromegrass with or without alfalfa or birdsfoot trefoil: heifer performance and sward characteristics. Prof. Anim. Sci. 15:130-135. https://doi.org/10.15232/S1080 $-7446(15) 31741-1$.

Boulton, A. C., J. Rushton, and D. C. Wathes. 2017. An empirical analysis of the cost of rearing dairy heifers from birth to first calving and the time taken to repay these costs. Animal 11:1372-1380. https://doi.org/10.1017/S1751731117000064.

Butler, W. R. 1998. Effect of protein nutrition on ovarian and uterine physiology in dairy cattle. J. Dairy Sci. 81:2533-2539. https://doi .org/10.3168/jds.S0022-0302(98)70146-8.

David, E. D., and W. D. Lindquist. 1982. Determination of the specific gravity of certain helminth eggs using sucrose density gradient centrifugation. J. Parasitol. 68:916-919. https://doi.org/10.2307/ 3281005 . 
Davis Rincker, L. E., M. J. VandeHaar, C. A. Wolf, J. S. Liesman, L. T. Chapin, and M. S. Weber Nielsen. 2011. Effect of intensified feeding of heifer calves on growth, pubertal age, calving age, milk yield, and economics. J. Dairy Sci. 94:3554-3567. https://doi.org/ 10.3168/jds.2010-3923.

Duplessis, M., R. Cue, D. Santschi, D. Lefebvre, and R. Lacroix. 2015. Weight, height, and relative-reliability indicators as a management tool for reducing age at first breeding and calving of dairy heifers. J. Dairy Sci. 98:2063-2073. https://doi.org/10.3168/jds.2014 -8279 .

Elsasser, T. H., T. S. Rumsey, and A. C. Hammond. 1989. Influence of diet on basal and growth hormone-stimulated plasma concentrations of IGF-I in beef cattle. J. Anim. Sci. 67:128-141. https://doi .org $/ 10.2527 /$ jas1989.671128x

Fenwick, M. A., R. Fitzpatrick, D. A. Kenny, M. G. Diskin, J. Patton, J. J. Murphy, and D. C. Wathes. 2008. Interrelationships between negative energy balance (NEB) and IGF regulation in liver of lactating dairy cows. Domest. Anim. Endocrinol. 34:31-44. https:// doi.org/10.1016/j.domaniend.2006.10.002.

Ferguson, J. D., T. Blanchard, D. T. Galligan, D. C. Hoshall, and W. Chalupa. 1988. Infertility in dairy cattle fed a high percentage of protein degradable in the rumen. J. Am. Vet. Med. Assoc. 192:659-662.

Ferguson, J. D., D. T. Galligan, T. Blanchard, and M. Reeves. 1993. Serum urea nitrogen and conception rate: The usefulness of test information. J. Dairy Sci. 76:3742-3746. https://doi.org/10.3168/ jds.S0022-0302(93)77716-4.

Funston, R. N., and D.M. Larson. 2011. Heifer development systems: Dry-lot feeding compared with grazing dormant winter forage. J. Anim. Sci. 89:1595-1602. https://doi.org/10.2527/jas.2010-3095.

Gabler, M. T., and A. J. Heinrichs. 2003. Dietary protein to metabolizable energy ratios on feed efficiency and structural growth of prepubertal Holstein heifer. J. Dairy Sci. 86:268-274. https://doi .org/10.3168/jds.S0022-0302(03)73605-4.

Habib, M. R., M. H. Rashid, M. A. Islam, S. Majumder, K. M. S. Islam, S. Ahmed, M. S. Alam, and E. Vargas-Bello-Pérez. 2018. Influence of green grass-based diets on growth and reproductive performance in dairy heifers. Trop. Anim. Health Prod. 50:889-895. https://doi.org/10.1007/s11250-018-1514-x.

Hayes, C. J., C. G. McAloon, C. I. Carty, E. G. Ryan, J. F. Mee, and L. O'Grady. 2019. The effect of growth rate on reproductive outcomes in replacement dairy heifers in seasonally calving, pasture-based systems. J. Dairy Sci. 102:5599-5611. https://doi .org/10.3168/jds.2018-16079.

Heinrichs, A. J., and C. M. Jones. 2016. Monitoring Dairy Heifer Growth. Penn State Extension. Pennsylvania State University.

Hoffman, P.C., N. M. Brehm, S. G. Price, and A. Prill-Adams. 1996. Effect of accelerated postpubertal growth and early calving on lactation performance of primiparous Holstein heifers. J. Dairy Sci. 79:2024-2031. https://doi.org/10.3168/jds.S0022-0302(96)76575 $-\mathrm{X}$.

Hwang, S. Y., M. J. Lee, and H. C. Peh. 2001. Diurnal variations in milk and blood urea nitrogen and whole blood ammonia nitrogen in dairy cows. Asian-Australas. J. Anim. Sci. 14:1683-1689. https: //doi.org/10.5713/ajas.2001.1683.

Kolver, E. S., and K. L. Macmillan. 1994. Variation in selected blood plasma constituents during the post-partum and breeding periods in dairy cows. N. Z. Vet. J. 42:161-166. https://doi.org/10.1080/ 00480169.1994.35813.

Lowe, J. K. II, C. N. Boyer, A. P. Griffith, J. C. Waller, G. E. Bates, P. D. Keyser, J. A. Larson, and E. Holcomb. 2016. The cost of feeding bred dairy heifers on native warm-season grasses and harvested feedstuffs. J. Dairy Sci. 99:634-643. https://doi.org/10.3168/jds $.2015-9475$

Macdonald, K. A., L. R. McNaughton, G. A. Verkerk, J. W. Penno, L. J. Burton, D. P. Berry, P. J. S. Gore, J. A. S. Lancaster, and C. W. Holmes. 2007. A comparison of three strains of Holstein-Friesian cows grazed on pasture: Growth, development, and puberty. J. Dairy Sci. 90:3993-4003. https://doi.org/10.3168/jds.2007-0119.

Marston, T. T., K. S. Lusby, and R. P. Wettemann. 1995. Effects of postweaning diet on age and weight at puberty and milk produc- tion of heifers. J. Anim. Sci. 73:63-68. https://doi.org/10.2527/ 1995.73163x.

McBride, W. D., and C. Greene. 2009. Characteristics, Costs, and Issues for Organic Dairy Farming. Economic Research Report 82. DIANE Publishing; USDA.

Min, B., T. Barry, G. Attwood, and W. McNabb. 2003. The effect of condensed tannins on the nutrition and health of ruminants fed fresh temperate forages: A review. Anim. Feed Sci. Technol. 106:3-19. https://doi.org/10.1016/S0377-8401(03)00041-5.

Mines, J. J. 1977. Modifications of the McMaster worm egg counting method. Aust. Vet. J. 53:342-343. https://doi.org/10.1111/j.1751 -0813.1977.tb00247.x.

Moriel, P., R. F. Cooke, D. W. Bohnert, J. M. B. Vendramini, and J. D. Arthington. 2012. Effects of energy supplementation frequency and forage quality on performance, reproductive, and physiological responses of replacement beef heifers. J. Anim. Sci. 90:2371-2380. https://doi.org/10.2527/jas.2011-4958.

Mullen, M. P., D. P. Berry, D. J. Howard, M. G. Diskin, C. O. Lynch, L. Giblin, D. A. Kenny, D. A. Magee, K. G. Meade, and S. M. Waters. 2011. Single nucleotide polymorphisms in the insulin-like growth factor 1 (IGF-1) gene are associated with performance in Holstein-Friesian dairy cattle. Front. Genet. 2:3. https://doi.org/ 10.3389/fgene.2011.00003

Niezen, J. H., H. A. Robertson, G. C. Waghorn, and W. A. G. Charleston. 1998. Production, faecal egg counts and worm burdens of ewe lambs which grazed six contrasting forages. Vet. Parasitol. 80:15-27. https://doi.org/10.1016/S0304-4017(98)00202-7.

NRC. 2001. Nutrient Requirements of Dairy Cattle. 7th rev. ed. National Academies Press.

Ordóñez, A., T. Parkinson, C. Matthew, C. Holmes, R. Miller, N. Lopez-Villalobos, J. Burke, and I. Brookes. 2007. Effects of application in spring of urea fertiliser on aspects of reproductive performance of pasture-fed dairy cows. N. Z. Vet. J. 55:69-76. https:/ /doi.org/10.1080/00480169.2007.36744.

Pace, M., C. Israelsen, and R. Larsen. 2019. Costs and returns for irrigated safflower, Northern Utah. Utah State University Extension Paper 2031. Utah State University.

Patra, A. K., and J. Saxena. 2011. Exploitation of dietary tannins to improve rumen metabolism and ruminant nutrition. J. Sci. Food Agric. 91:24-37. https://doi.org/10.1002/jsfa.4152.

Pirlo, G., F. Miglior, and M. Speroni. 2000. Effect of age at first calving on production traits and on difference between milk yield returns and rearing costs in Italian Holsteins. J. Dairy Sci. 83:603608. https://doi.org/10.3168/jds.S0022-0302(00)74919-8.

Raeth-Knight, M., H. Chester-Jones, S. Hayes, J. Linn, R. Larson, D. Ziegler, B. Ziegler, and N. Broadwater. 2009. Impact of conventional or intensive milk replacer programs on Holstein heifer performance through six months of age and during first lactation. J. Dairy Sci. 92:799-809. https://doi.org/10.3168/jds.2008-1470.

Rajala-Schultz, P. J., W. J. A. Saville, G. S. Frazer, and T. E. Wittum. 2001. Association between milk urea nitrogen and fertility in Ohio dairy cows. J. Dairy Sci. 84:482-489. https://doi.org/10.3168/jds .S0022-0302(01)74498-0.

Roche, J. R., N. A. Dennis, K. A. Macdonald, C. V. C. Phyn, P. R. Amer, R. R. White, and J. K. Drackley. 2015. Growth targets and rearing strategies for replacement heifers in pasture-based systems: A review. Anim. Prod. Sci. 55:902-915. https://doi.org/10.1071/ AN14880.

Roche, J. R., S. Petch, and J. K. Kay. 2005. Manipulating the dietary cation-anion difference via drenching to early-lactation dairy cows grazing pasture. J. Dairy Sci. 88:264-276. https://doi.org/10 .3168/jds.S0022-0302(05)72684-9.

Rose, M. F., B. L. Waldron, S. C. Isom, M. D. Peel, K. J. Thornton, R. Miller, K. A. Rood, J. A. Hadfield, J. Long, B. Henderson, and J. E. Creech. 2021. The effects of organic grass and grass-birdsfoot trefoil pastures on Jersey heifer development: Herbage characteristics affecting intake. J. Dairy Sci. 104:10879-10895. https://doi .org/10.3168/jds.2020-19563.

Saha, U. K., L. S. Sonon, D. W. Hancock, N. S. Hill, L. Stewart, G. L. Heusner, and D. E. Kissel. 2010. Common terms used in animal 
feeding and nutrition. University of Georgia Cooperative Extension Bulletin 1367. University of Georgia.

Shepley, E., E. Vasseur, R. Bergeron, A. Villeneuve, and S. Lachance. 2015. Short communication: Birdsfoot trefoil as a preventative treatment for gastrointestinal nematodes in pastured dairy heifers. Can. J. Anim. Sci. 95:533-537. https://doi.org/10.4141/cjas $-2014-169$.

Siadkowska, E., L. Zwierzchowski, J. Oprzadek, N. Strzalkowska, E. Bagnicka, and J. Krzyzewski. 2006. Effect of polymorphism in IGF-1 gene on production traits in Polish Holstein-Friesian cattle. Anim. Sci. Pap. Rep. 24:225-237.

Tozer, P. R., F. Bargo, and L. D. Muller. 2003. Economic analyses of feeding systems combining pasture and total mixed ration. J. Dairy Sci. 86:808-818. https://doi.org/10.3168/jds.S0022-0302(03)73663 -7 .

Tozer, P., and A. Heinrichs. 2001. What affects the costs of raising replacement dairy heifers: A multiple-component analysis. J. Dairy Sci. 84:1836-1844. https://doi.org/10.3168/jds.S0022 -0302(01)74623-1.

USDA-AMS. 2019. Guidelines for Organic Certification of Dairy Livestock. USDA.

Utah Climate Center. 2018. Accessed Jul. 7, 2020. https://climate.usu .edu/index.php.

Waldron, B. L., T. J. Bingham, J. E. Creech, M. D. Peel, R. Miller, K. B. Jensen, D. R. ZoBell, J.-S. Eun, K. Heaton, and D. L. Snyder. 2020. Binary mixtures of alfalfa and birdsfoot trefoil with tall fescue: Herbage traits associated with the improved growth performance of beef steers. Grassl. Sci. 66:74-87. https://doi.org/ $10.1111 /$ grs. 12257 .

Zanton, G. I., and A. J. Heinrichs. 2005. Meta-analysis to assess effect of prepubertal average daily gain of Holstein heifers on first- lactation production. J. Dairy Sci. 88:3860-3867. https://doi.org/ 10.3168/jds.S0022-0302(05)73071-X.

Zanton, G. I., and A. J. Heinrichs. 2007. The effects of controlled feeding of a high-forage or high-concentrate ration on heifer growth and first-lactation milk production. J. Dairy Sci. 90:3388-3396. https://doi.org/10.3168/jds.2007-0041.

Zhang, J., H. Shi, Y. Wang, S. Li, H. Zhang, Z. Cao, and K. Yang. 2018. Effects of limit-feeding diets with different forage-to-concentrate ratios on nutrient intake, rumination, ruminal fermentation, digestibility, blood parameters and growth in Holstein heifers. Anim. Sci. J. 89:527-536. https://doi.org/10.1111/asj.12959.

\section{ORCIDS}

Jacob A. Hadfield ๑ https://orcid.org/0000-0002-8415-4191

Blair L. Waldron ํㅜ https://orcid.org/0000-0003-3735-5326

S. Clay Isom @ \ttps://orcid.org/0000-0001-6029-6753

Ryan Feuz @ https://orcid.org/0000-0001-9464-201X

J. Earl Creech ๑ https://orcid.org/0000-0002-4393-6816

Marcus F. Rose 누 https://orcid.org/0000-0002-9553-7796

Jenny Long (으 https://orcid.org/0000-0001-8805-0456

Michael D. Peel $\odot$ https://orcid.org/0000-0002-3122-5486

Rhonda L. Miller @ https://orcid.org/0000-0003-0620-6862

Kerry A. Rood ๑ https://orcid.org/0000-0001-6655-5381

Allen Young 우 https://orcid.org/0000-0002-3073-6743

Kara J. Thornton 주 https://orcid.org/0000-0002-7506-5293 